\title{
Prevalence and factors associated with shoulder pain in the general population: a cross-sectional study
}

\author{
Prevalência e fatores associados com dor no ombro na população geral: um estudo transversal \\ Prevalencia y factores asociados con el dolor de hombro en la población general: un estudio \\ transversal
}

Thiago Paulo Frascareli Bento', Caio Vitor dos Santos Genebra², Guilherme Porfírio Cornélio
Rangel Dal Bello Biancon ${ }^{4}$, Sandra Fiorelli Almeida Penteado Simeão ${ }^{5}$ Alberto De Vitta

\begin{abstract}
Musculoskeletal pain in the shoulder is considered one of the most prevalent causes of pain and disability in adults. To verify the prevalence of shoulder pain and correlated factors in adults aged 20 years or older in cross-sectional study with 600 individuals interviewed through questionnaires: (1) participants characterization; (2) level of physical activity; (3) reported morbidities; and (4) musculoskeletal symptoms. Descriptive, bivariate, and Poisson regression analyses were performed. The prevalence of pain in the shoulder was $24 \%(\mathrm{Cl} 20.3 \%-27.5 \%)$. Being 60 years or older $(P R=2.14 ; 1.33-2.45)$, female $(P R=1.92$; 1.29-285), using the computer more than three times a week $(P R=1.55$; 1.01-2.32), working in a sitting position ( $P R=1.64$; 1.03-2.59), standing up leaning the body forward ( $P R=1.54$; 1.00-2.37), and reporting two or more morbidities ( $P R=3.31$; 1.97-5.57) were all indicators of shoulder pain. This study discloses a high prevalence of shoulder pain and a strong relation with women, age, those who use the computer more than three times a week, those who execute occupational activities sitting and standing up leaning the body forward, and those who report two or more diseases.

Keywords | Prevalence; Risk Factors; Shoulder; Epidemiology; Cross-Sectional Studies.
\end{abstract}

RESUMO I A dor musculoesquelética no ombro é considerada uma das causas mais prevalentes de dor e incapacidade em adultos. O objetivo foi verificar a prevalência de dor no ombro e fatores correlacionados em adultos de 20 anos ou mais em estudo transversal com 600 indivíduos entrevistados por meio de questionários que identificaram: (1) caracterização dos participantes; (2) nível de atividade física; (3) morbidades relatadas; e (4) sintomas musculoesqueléticos. Foram realizadas análises descritiva, bivariada e de Poisson. A prevalência de dor no ombro foi de 24\% (IC 20,3\%-27,5\%). Ter 60 anos ou mais (PR=2.14; 1.33-2.45); ser do sexo feminino ( $P R=1.92 ; 1.29-285)$; usar o computador mais de três vezes por semana (PR=1.55; 1.01-2.32); trabalhar em posição sentada ( $P R=1.64 ; 1.03-2.59)$; trabalhar de pé, inclinando o corpo para a frente ( $P R=1.54 ; 1.00-2.37)$; e relatar duas ou mais morbidades ( $P R=3.31$; 1.97-5.57) foram indicadores de dor no ombro. 0 estudo revelou alta prevalência de dor no ombro e uma forte relação com ser mulher, ter idade maior que 60 anos, usar o computador mais de três vezes por semana, executar atividades ocupacionais sentado ou de pé, inclinando o corpo para a frente, e relatar duas ou mais doenças.

Descritores | Prevalência; Fatores de Risco; Ombro; Epidemiologia; Estudos Transversais.

RESUMEN | El dolor musculoesquelético en el hombro es una de las causas más frecuentes de dolor y discapacidad en adultos. El presente artículo tuvo el objetivo de verificar la prevalencia de dolor de hombro

Study conducted at Universidade do Sagrado Coração (USC), Bauru, SP, Brazil.

'Universidade do Sagrado Coração (USC) - Bauru (SP), Brazil. E-mail: thibento10@gmail.com. Orcid: 0000-0003-2394-8024 2Universidade do Sagrado Coração (USC) - Bauru (SP), Brazil. E-mail: caio.vitor92@yahoo.com. Orcid: 0000-0001-5882-7025 ¿Universidade do Sagrado Coração (USC) - Bauru (SP), Brazil. E-mail: guiporfirio96@gmail.com. Orcid: 0000-0003-3010-1796 ${ }^{4}$ Universidade do Sagrado Coração (USC) - Bauru (SP), Brazil. E-mail: rangel.biancon@hotmail.com. Orcid: 0000-0003-3382-2599 5 Universidade do Sagrado Coração (USC) - Bauru (SP), Brazil. E-mail: sandrasimeao@uol.com.br. Orcid: 0000-0002-3291-278X 6Universitade Anhanguera-Uniderp - Campo Grande (MS), Brazil. E-mail: albvitta@gmail.com. Orcid: 0000-0002-3248-456X 
y factores correlacionados en adultos mayores de 20 años. Estudio transversal con 600 individuos entrevistados mediante cuestionarios que han identificado: (1) caracterización de los participantes; (2) nivel de actividad física; (3) morbilidades reportadas; y (4) síntomas musculoesqueléticos. Se realizaron análisis descriptivos, bivariados y de Poisson. La prevalencia del dolor de hombro fue del 24\% (IC 20,3\%-27,5\%). Los indicadores de dolor del hombro fueron: tener 60 años o más ( $P R=2.14 ; 1.33-2.45$ ); ser mujer ( $P R=1.92 ; 1.29-285)$; usar la computadora más de tres veces por semana ( $P R=1.55 ; 1.01-2.32)$; trabajar en una posición sentada ( $P R=1.64$; 1.03-2.59); trabajar de pie inclinando el cuerpo hacia adelante ( $P R=1.54$; 1.00-2.37); e informar dos o más morbilidades ( $P R=3.31 ; 1.97-5.57)$. El estudio reveló una alta prevalencia de dolor en el hombro y una fuerte relación con ser mujer, mayor de 60 años, usar la computadora más de tres veces por semana, realizar actividades ocupacionales sentado o de pie inclinándose hacia adelante, e informar la existencia de dos o más enfermedades.

Palabras clave | Prevalencia; Factores de Riesgo; Hombro; Epidemiologia; Estudios Transversales.

\section{INTRODUCTION}

Shoulder pain is the third most common musculoskeletal condition in the primary health care system - with an annual prevalence between 4.7 and $46.7^{1-3}$ - following the low back and neck pain, respectively, with $13 \%$ to $65 \%^{4}$ and $16.7 \%$ to $75.1 \% 5$.

Studies show the relation between shoulder pain and some correlated factors, such as being women, performing manual movements above the shoulder level, using vibrating tools, sitting in a position with cervical spine flexion, work standing, performing hard and repetitive physical work, and using the computer daily ${ }^{1-7}$. Besides these biomechanical work constraints, psychosocial risk factors (high demand, lack of autonomy, and low social support) and psychological illnesses (depression and anxiety) have been identified ${ }^{8-10}$.

Shoulder pain is a musculoskeletal condition i.e. a significant cause of morbidity and functional disability in occupational and daily life activities, contributing to increased social and economic costs for individuals, businesses and the State ${ }^{11}$.

In Brazil and worldwide, there is little information available about the epidemiology and clinical characteristics of shoulder pain, mainly in population-based studies. Furthermore, current research about shoulder pain is predominantly related to work factors, not focusing on individual factors and life habits ${ }^{12}$.

The knowledge of the prevalence of shoulder pain, its clinical aspects, and risk factors are important, since musculoskeletal conditions affect populations of different age groups and sex. Thus, this knowledge will enable health professionals to provide patients with adequate information about the most likely course of their symptoms, prognostic information to distinguish between patients with favorable outcomes and those with a high risk of chronic shoulder pain and disability, and to implement curative and preventive interventions ${ }^{13}$.

This study aims to verify the prevalence of shoulder pain in a sample population of adults, aged 20 years or older, as well as analyze the correlations between shoulder pain and demographic, socioeconomic, and ergonomic aspects related to lifestyle and reported morbidities.

\section{METHODOLOGY}

This cross-sectional study was conducted in the urban area of Bauru. The age and sex groups, denominated sample domains - 20 to 35 years-old men; 20 to 35 yearsold women; 36 to 59 ,years-old men; 36 to 59 years-old women; 60 year-old and older men; and 60 year-old and older women - were first defined with a minimum number of individuals per sample.

To calculate the sample size, was used a estimated proportion of $50 \%$ of the population subgroups with confidence level of $95 \%$ in the estimation intervals as well as a sampling error of $10 \%$, and a design effect (DEFF) of $2 \%$. Therefore, the sample size for each group was at least 200 individuals (100 men and 100 women), totaling 600 participants.

The sample was taken from a two-stage cluster - the primary sampling units (PSU) were the census sectors, and the secondary sampling units, the residences. The PSU were collected by systematic sampling with probability proportional to their size. The sampling units were obtained from the 2011 National Household Sample Survey (PNAD). In total, 50 urban census sectors were taken from the 476 identified sectors. 
It was decided that about 12 families should be visited for each census sector by calculating the ratio of the average number of individuals to the number of households. Households were systematically drawn and all individuals residing in them were eligible. A new home was randomly selected in case of refusal. Individuals not found after four visits (of which at least one occurred at night and one on the weekend) were considered as loss. Those who refused to answer the questionnaire were considered as refusals.

Individuals who were living in institutions such as nursing homes and prisons and those who were unable to answer the questionnaire were excluded from the study. Some older adults underwent the Mini Mental State Examination and those who scored below 27 points were excluded from the study ${ }^{14}$. Data were collected from February to June 2012. Interviewers and senior Physical therapy students were submitted to theoretical and practical training.

The variable "shoulder pain" was assessed using the Nordic questionnaire, validated and adapted to the Brazilian culture ${ }^{15}$. Shoulder pain was defined as a pain located at a restricted area in or around the shoulder complex ${ }^{16}$. In the interview, individuals were asked: "Have you had any pain or discomfort in the shoulder area in the past year?"15.

Individual factors included sex, age, marital status, education, race and, income. The questions regarding devices electronics - TV, computer or playing video games - were "Do you watch TV during the week?"; "How many times do you watch TV during the week?"; "How many hours do you watch TV in a typical day?"; "How often do you use the computer or play video games in a typical week?"; "For how many hours do you use a computer or play video games on a typical day?"17.

The ergonomic variables - repetitive movements, heavy lifting, vibration/tremor during the working day, sitting position, forward leaning position, weighted sitting position, postural orthostatic, forward flexed, kneeling and lying posture - were characterized by the options that best describe their exposure frequency during a workday as follows: never, rarely, usually, always.

Smokers were those who reported smoking daily (at least one cigarette per day) or occasionally (less than one cigarette per day) or former smokers who had stopped smoking for at least six months prior to the interview ${ }^{18}$. Morbidities and health problems were assessed by selfreport of the presence in the last 12 months.

The level of physical activity was verified by the International Physical Activity Questionnaire (IPAQ) ${ }^{19}$, short version. For the classification of the subjects in the levels of physical activity, IPAQ official categories were used - insufficiently active, sufficiently active and very active ${ }^{19}$.

The data obtained were inserted into a database using SPSS statistical software, version 10.0 (SPSS, Chicago, United States). Absolute and relative frequency distributions were performed for categorical variables, as well as the calculation of prevalence ratios (PR) with 95\% confidence interval (CI). Poisson regression was utilized to analyze the variables associated with shoulder pain, respecting a hierarchical model of relationships among the variables. The prevalence ratios were calculated, as well as their respective $95 \%$ confidence intervals.

\section{RESULTS}

The drawn residences included 641 eligible subjects, of which only 600 were effectively interviewed. The main reasons for loss (No.=41) were: "absent residents" and "scheduled with the interviewer but did not attend". Refusals were: "I do not respond to interviews" and "too long, it will take a long time to respond". Most participants had between 9 and 11 years of formal education, were white, married, of low income, non-smoker, and sedentary.

Regarding the total of individuals, 24\% (CI 20.3\% to $27.5 \%$ ) of 600 reported pain in the shoulder at least once in the 12 months prior to the interview; 55 representing $18.3 \%$ (CI $14.3 \%$ to $23.1 \%$ ) of the total, were men; and 89 representing $29.7 \%$ (CI $24.7 \%$ to $35 \%$ ) of the total, were women.

It was possible to notice an association of pain in the shoulder with being female, older than 60 years, black and brown-skinned individuals, widowed or separated, and those who presented two or more reported morbidities (Table 1).

Concerning sedentary activities, there was no association between the studied variables and pain in the shoulder (Table 2).

There was no association of outcome with ergonomic variables (Table 3).

The adjusted analysis showed that being 60 years or older ( $\mathrm{PR}=2.14$; 1.33-2.45), female ( $\mathrm{PR}=1.92 ; 1.29-2.85)$, using the computer up to three times per week $(\mathrm{PR}=1.55 ; 1.01$ $2.32)$, work in a sitting position $(\mathrm{PR}=1.64 ; 1.03-2.59)$, work standing with the body tilted ( $\mathrm{PR}=1.54 ; 1.00-2.37)$, and reporting two or more morbidities $(\mathrm{PR}=3.31$ : 1.97-5.57) remained associated with shoulder pain (Table 4). 
Table 1. Prevalence of shoulder pain by demographic and socioeconomic characteristics, level of physical activity, reported morbidities, and smoking

\begin{tabular}{|c|c|c|c|c|}
\hline \multirow{3}{*}{ Variables } & \multirow{3}{*}{ Total } & \multicolumn{3}{|c|}{ Shoulder pain } \\
\hline & & \multicolumn{3}{|c|}{ Prevalence } \\
\hline & & No. & $\%$ & PR (Cl 95\%) \\
\hline \multicolumn{5}{|l|}{ Sex } \\
\hline Male & 300 & 55 & 18.3 & 1.00 \\
\hline Female & 300 & 89 & 29.7 & $1.62(1.20-2.17)$ \\
\hline \multicolumn{5}{|l|}{ Age group } \\
\hline 20 to 35 years & 200 & 35 & 17.5 & 1.00 \\
\hline 36 to 59 years & 200 & 47 & 23.5 & 1.34 (0.91-1.99) \\
\hline 60 or more & 200 & 62 & 31 & $1.77(1.23-2.55)$ \\
\hline \multicolumn{5}{|l|}{ Education } \\
\hline 12 years or more & 105 & 20 & 19 & 1.00 \\
\hline 9 to 11 years & 244 & 53 & 21.7 & $1.14(0.72-1.81)$ \\
\hline 5 to 8 years & 129 & 36 & 27.9 & $1.47(0.90-2.37)$ \\
\hline 0 to 4 years & 122 & 35 & 28.7 & $1.51(0.93-2.44)$ \\
\hline \multicolumn{5}{|l|}{ Race } \\
\hline White & 480 & 115 & 24 & 1.00 \\
\hline Black & 38 & 27 & 71.1 & $2.97(2.29-3.84)$ \\
\hline Brown-skinned & 82 & 64 & 78 & $3.26(2.68-3.96)$ \\
\hline \multicolumn{5}{|l|}{ Marital Status } \\
\hline Married & 345 & 76 & 22 & 1.00 \\
\hline Single & 150 & 30 & 20 & $0.91(0.62-1.32)$ \\
\hline Widow(er)/ Divorced & 105 & 38 & 36.2 & $1.62(1.19-2.27)$ \\
\hline \multicolumn{5}{|l|}{ Income } \\
\hline High & 140 & 17 & 23.9 & 1.00 \\
\hline Medium & 71 & 28 & 20 & $0.84(0.49-1.42)$ \\
\hline Low & 389 & 99 & 25.4 & $1.06(0.68-1.66)$ \\
\hline \multicolumn{5}{|l|}{ Smoking } \\
\hline Non-smoker & 363 & 91 & 25.1 & 1.00 \\
\hline Ex-smoker & 128 & 28 & 21.9 & $0.87(0.60-1.27)$ \\
\hline Smoker & 109 & 25 & 22.9 & $0.91(0.62-1.35)$ \\
\hline \multicolumn{5}{|l|}{ Reported Morbidities } \\
\hline None & 177 & 22 & 12.4 & 1.00 \\
\hline One & 138 & 24 & 17.4 & $1.40(0.82-2.39)$ \\
\hline Two or more & 285 & 98 & 34.4 & $2.77(1.81-4.22)$ \\
\hline \multicolumn{5}{|l|}{ Level of physical activity } \\
\hline Very active & 101 & 24 & 23.7 & 1.00 \\
\hline Sufficiently active & 109 & 25 & 22.9 & $0.96(0.57-1.61)$ \\
\hline Insufficiently active & 390 & 95 & 24.4 & $0.92(0.55-1.52)$ \\
\hline
\end{tabular}

Table 2. Prevalence of shoulder pain by sedentary activities

\begin{tabular}{|c|c|c|c|c|}
\hline \multirow{3}{*}{ Variables } & \multirow{3}{*}{ Total } & \multicolumn{3}{|c|}{ Shoulder pain } \\
\hline & & \multicolumn{3}{|c|}{ Prevalence } \\
\hline & & No. & $\%$ & PR (Cl 95\%) \\
\hline \multicolumn{5}{|l|}{ Watching TV } \\
\hline No & 34 & 9 & 26.5 & 1.00 \\
\hline Yes & 566 & 135 & 23.9 & $0.90(0.50-1.61)$ \\
\hline \multicolumn{5}{|c|}{ Time watching TV a week } \\
\hline Up to 2 & 26 & 3 & 11.5 & 1.00 \\
\hline 3 or more & 540 & 132 & 24.4 & $2.72(0.72-6.20)$ \\
\hline \multicolumn{5}{|c|}{ Hours watching TV a day } \\
\hline Up to 2 & 303 & 72 & 23.8 & 1.00 \\
\hline More than 3 & 263 & 63 & 24 & $1.01(0.75-1.35)$ \\
\hline \multicolumn{5}{|c|}{ Computer or video game use } \\
\hline No & 286 & 92 & 29.3 & 1.00 \\
\hline Yes & 314 & 52 & 18.2 & $0.62(0.46-0.84)$ \\
\hline \multicolumn{5}{|c|}{ Time using a computer or playing video game a week } \\
\hline Up to 2 & 37 & 11 & 29.7 & 1.00 \\
\hline 3 or more & 249 & 41 & 16.5 & $0.55(0.31-0.98)$ \\
\hline \multicolumn{5}{|c|}{ Hours using a computer or playing video game a day } \\
\hline Up to 2 & 159 & 29 & 18.2 & 1.00 \\
\hline More than 3 & 127 & 23 & 18.1 & $0.99(0.61-1.63)$ \\
\hline
\end{tabular}

Table 3. Prevalence of shoulder pain by ergonomics or work variables

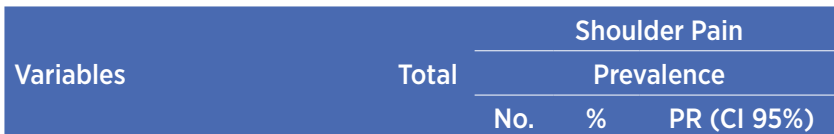

Repetitive movement

$\begin{array}{llllr}\text { Never/rarely } & 240 & 52 & 21.7 & 1.00\end{array}$

Always/usually

$268 \quad 92 \quad 25.6 \quad 1.18(0.88-1.59)$

Vibration/trepidation

$\begin{array}{lllll}\text { Never/rarely } & 505 & 121 & 24 & 1.00\end{array}$

Always/usually

$\begin{array}{llll}95 & 23 & 24.2 & 1.01(0.69-1.49)\end{array}$

Transport and weight carrying

$\begin{array}{lllll}\text { Never/rarely } & 400 & 95 & 23.8 & 1.00\end{array}$

Always/usually

$200 \quad 49 \quad 24.5 \quad 1.03(0.76-1.39)$

Sitting position

$\begin{array}{llllr}\text { Never/rarely } & 223 & 48 & 21.5 & 1.00\end{array}$

Always/usually

$377 \quad 96 \quad 25.5 \quad 1.18(0.87-1.60)$

Sitting and lifting weight

$\begin{array}{lrrrr}\text { Never/rarely } & 551 & 136 & 24.7 & 1.00 \\ \text { Always/usually } & 49 & 8 & 16.3 & 0.66(0.35-1.27)\end{array}$

Sitting and leaning the body forward

$\begin{array}{llllr}\text { Never/rarely } & 156 & 42 & 26.9 & 1.00\end{array}$

Always/usually $\quad 444 \quad 102 \quad 23 \quad 1.17(0.86-1.60)$

Standing position

$\begin{array}{lllll}\text { Never/rarely } & 458 & 33 & 24.2 & 1.00\end{array}$

$\begin{array}{lllll}\text { Always/usually } & 142 & 111 & 23.2 & 1.04(0.74-1.47)\end{array}$

Standing up leaning the body forward

$\begin{array}{lrrrr}\text { Never/rarely } & 291 & 69 & 22.3 & 1.00 \\ \text { Always/usually } & 309 & 75 & 25.8 & 0.87(0.65-1.15)\end{array}$


Table 4. Poisson regression analysis, final model, relations of the variables studied with shoulder pain

\begin{tabular}{|c|c|c|}
\hline \multirow{2}{*}{ Factors } & \multicolumn{2}{|c|}{ Shoulder pain } \\
\hline & p-value & Adjusted PR/CI 95\% \\
\hline \multicolumn{3}{|l|}{ Sex } \\
\hline Male & - & 1.00 \\
\hline Female & 0.001 & $1.92(1.29-2.85)$ \\
\hline \multicolumn{3}{|l|}{ Age group } \\
\hline 20 to 35 years & - & 1.00 \\
\hline 36 to 59 years & 0.12 & $1.45(0.88-2.38)$ \\
\hline 60 or older & 0.002 & $2.14(1.33-2.45)$ \\
\hline \multicolumn{3}{|l|}{ Reported diseases } \\
\hline None & - & 1.00 \\
\hline One & 0.29 & $1.48(0.79-2.77)$ \\
\hline Two or more & 0.001 & $3.31(1.97-5.57)$ \\
\hline \multicolumn{3}{|c|}{ Time using the computer a week } \\
\hline Up to 2 times & - & 1.00 \\
\hline 3 to 4 times & 0.04 & $1.55(1.01-2.32)$ \\
\hline \multicolumn{3}{|l|}{ Sitting Position } \\
\hline Never/rarely & - & 1.00 \\
\hline Always/usually & 0.03 & $1.64(1.03-2.59)$ \\
\hline \multicolumn{3}{|c|}{ Standing up leaning the body forward } \\
\hline Never/rarely & - & 1.00 \\
\hline Always/usually & 0.05 & $1.54(1.00-2.37)$ \\
\hline
\end{tabular}

\section{DISCUSSION}

In this study, the prevalence of shoulder pain was $24 \%$ lower than that found in Japan $(30 \%)^{1}$, Netherlands $(48 \%)^{3}$, and China $(48.7 \%)^{2}$. A possible reason for these variations is that few studies have uniformly defined the clinical condition and anatomical area of the cervical and shoulder regions ${ }^{1}$.

Shoulder pain was associated with individuals 60 years or older, similar to the study in the Netherlands ${ }^{3}$, while in Japan it was associated with young adults ${ }^{20}$. The increased risk of shoulder pain in older adults is due to degenerative changes in muscles, tendons, ligaments and joints inherent in the natural process of senescence, chronic overload for the old aged worker and long-term exposure to occupational risk factors ${ }^{3}$.

Women were associated with the outcome, corroborating other studies ${ }^{1,2,6}$. These differences are due to greater exposure to static position, monotonous and repetitive tasks in daily life as well as domestic tasks, and to a lower pain threshold ${ }^{1,2,6}$. A Japanese study noted that women felt more stress and had more concerns, having negative effects on the muscles of the cervical and shoulder region. Although the sex distinction is still controversial, psychosocial and biological sex differences affect the occurrence of shoulder pain ${ }^{1}$.

The use of computer more than three times a week and work sitting have been associated with shoulder pain, according to some findings $\mathrm{s}^{2,6}$. These factors associated with poor postural habits, ergonomically inadequate environments, and psychosocial factors lead to static contraction of shoulder muscles, contributing to the development of inflammatory processes in musculoskeletal structures ${ }^{21}$. However, a systematic review reported that sitting position is not a relevant risk factor for shoulder pain ${ }^{22}$.

Those works that require body tilting while standing remained associated with the outcome, similar to other studies $^{2,22}$. Review studies have reported an association with occupational activities requiring upper limb strength, load lifting, repetitive shoulder and hand movements, using vibrating tools, hand raising above shoulder level, and the combination of these factors ${ }^{23}$.

The outcome was associated with two or more reported morbidities. The literature does not indicate the association of morbidities with shoulder pain. However, two studies on chronic lumbar musculoskeletal pain reported that pain is more commonly related in individuals with other associated chronic morbidities. The association of symptoms with diseases can be interpreted as cause or effect, due to the cross-sectional design of the studies.

This study had as limitations the non-collection of data regarding frequency, severity, intensity, and duration of pain, as well as psychological factors and how the shoulder discomfort affected and/or reduced occupational and daily life activities. Furthermore, the use of selfreport to measure the work conditions also limited the study outcomes. This study results are consistent with the literature, and it is consisted by a large number of interviews, representing its strong points.

This study will contribute as a reference for other epidemiological investigations and contribute to knowledge on the national prevalence estimative and its risk factors for systematic reviews and meta-analysis. Moreover, in Brazil the availability of national research data related to the result is scarce.

It was concluded that shoulder pain had a high prevalence and is associated with women, older aged, using the computer more than three times a week, performing occupational activities in the sitting position, incorrect sit-to-stand movement, and reporting two or more morbidities. 


\section{REFERENCES}

1. Takasawa E, Yamamoto A, Kobayashi T, Tajika T, Shitara H, Ichinose T, et al. Characteristics of neck and shoulder pain in the Japanese general population. J Orthop Sci. 2015;20(2):403-9. doi: 10.1007/s00776-014-0676-2

2. Yue P, Liu F, Li L. Neck/shoulder pain and low back pain among school teachers in China, prevalence and risk factors. BMC Public Health. 2012;12:789. doi: 10.1186/1471-2458-12-789

3. Greving KL, Dorrestijn O, Winters JC, Groenhof F, Van Der Meer $K$, Stevens M, et al. Incidence, prevalence, and consultation rates of shoulder complaints in general practice. Scand J Rheumatol. 2012;41(2):150-5. doi: 10.3109/03009742.2011.605390

4. Nascimento PR, Costa LO. Low back pain prevalence in Brazil: a systematic review. Cad Saude Publica. 2015;31(6):1141-56. doi: 10.1590/0102-311X00046114

5. Genebra CVDS, Maciel NM, Bento TPF, Simeão SFAP, Vitta AD. Prevalence and factors associated with neck pain: a populationbased study. Braz J Phys Ther. 2017;21(4):274-80. doi: 10.1016/j. bjpt.2017.05.005

6. Ranasinghe P, Perera YS, Lamabadusuriya DA, Kulatunga S, Jayawardana N, Rajapakse S, et al. Work related complaints of neck, shoulder and arm among computer office workers: a crosssectional evaluation of prevalence and risk factors in a developing country. Environ Health. 2011;10:70. doi: 10.1186/1476-069X-10-70

7. Sadeghian F, Raei M, Amir M. Persistent of Neck/shoulder pain among computer office workers with specific attention to pain expectation, somatization tendency, and beliefs. Int J Prev Med. 2014 5(9):1169-77.

8. Linaker $\mathrm{CH}$, Walker-Bone K. Shoulder disorders and occupation. Best Pract Res Clin Rheumatol. 2015;29(3):405-23. doi: 10.1016/j. berh.2015.04.001

9. Gill TK, Shanahan EM, Taylor AW, Buchbinder R, Hill CL. Shoulder pain in the community: an examination of associative factors using a longitudinal cohort study. Arthritis Care Res. 2013;65:2000-7. doi: 10.1002/acr.22082

10. Chester R, Jerosch-Herold C, Lewis J, Chepstone L. Psychological factors are associated with the outcome of physiotherapy for people with shoulder pain: a multicentre longitudinal cohort study. Br J Sports Med. 2018;(52)4:269-75. doi: 10.1136/ bjsports-2016-096084

11. Waersted M, Hanvold TN, Veiersted KB. Computer work and musculoskeletal disorders of the neck and upper extremity: a systematic review. BMC Musculoskeletal Disord. 2010;11:79. doi: 10.1186/1471-2474-11-79
12. Bodin J, Ha C, Sérazin C, Descatha A, Leclerc A, Goldberg M, Roquelaure $Y$. Effects of individual and work-related factors on incidence of shoulder pain in a large working population. J Occup Health. 2012;54(4):278-88. doi: 10.1539/joh.11-0262-ao

13. Oakman J, Keegel T, Kinsman N, Briggs AM. Persistent musculoskeletal pain and productive employment; a systematic review of interventions. Occup Environ Med. 2016;73(3):206-14. doi: 10.1136/oemed-2015-103208

14. Folstein MF, Folstein SE, McHugh PR. "Mini-mental state": a practical method for grading the cognitive state of patients for the clinician. J Psychiatr Res. 1975;12(3):189-98. doi: 10.1016/0022-3956(75)90026-6

15. Barros ENC, Alexandre NMC. Cross-cultural adaptation of the Nordic Musculoskeletal Questionnaire. Int Nurs Rev. 2003;50(2):101-8. doi: 10.1046/j.1466-7657.2003.00188.x

16. Pope DP, Croft PR, Pritchard CM, Silman A. Prevalence of shoulder pain in the community: the influence of case definition. Ann Rheum Dis. 1997;56(5):308-12. doi: 10.1136/ard.56.5.308

17. Fernandes JAA, Genebra CVS, Maciel NM, Fiorelli A, Conti MHS, De Vitta A. Low back pain in schoolchildren: a cross-sectional study in a western city of São Paulo State, Brazil. Acta Ortop Bras. 2015;23(5):235-8. doi: 10.1590/1413-785220152305148842

18. World Health Organization. Guidelines for controlling and monitoring the tobacco epidemic [Internet]. Geneva: WHO; 1998 [cited 2019 Sept 20]. Available from: https://bit.ly/2m507gw

19. International Physical Activity Questionnaire. Guidelines for data processing and analysis of the International Physical Activity Questionnaire (IPAQ): short and long forms. IPAQ; 2005 [cited 2010 Dec 12]. Available from: https://bit.ly/33NvkZ2

20. lizuka Y, lizuka H, Mieda T, Tajika T,Yamamoto A, Ohsawa T, et al. Association between neck and shoulder pain, back pain, low back pain and body composition parameters among the Japanese general population. BMC Musculoskeletal Disorders. 2015;16:333. DOI:10.1186/s12891-015-0759-z

21. Hallman DM, Gupta N, Mathiassen SE, Holtermann A. Association between objectively measured sitting time and neck-shoulder pain among bluecollar workers. Int Arch Occup Environ Health. 2015;88(8):1031-42. doi: 10.1007/s00420-015-1031-4

22. Mayer J, Kraus T, Ochsmann E. Longitudinal evidence for the association between work-related physical exposures and neck and/or shoulder complaints: a systematic review. Int Arch Occup Environ Health. 2012;85(6):587-603. doi: 10.1007/ s00420-011-0701-0

23. Van Rijn RM, Huisstede BMA, Koes BW, Burdorf A. Associations between work-related factors and specific disorders of the shoulder: a systematic review of the literature. Scand J Work Environ Health. 2010;36(3):189-201. doi: 10.5271/sjweh.2895 